\title{
CHALLENGE OF COMMUNITY BASED FISH CULTURE PROGRAM IN BANGLADESH: CASE STUDY ON FLOODPLAIN BEEL MAIL IN RAJSHAHI
}

\author{
Md. Istiaque Hossain* \\ Associate Professor \\ Department of Fisheries, Faculty of Agriculture \\ University of Rajshahi, Bangladesh \\ Email: bitanrubd@yahoo.com \\ Chamhuri Siwar \\ Emeritus Professor \\ Institute for Environment and Development (LESTARI) \\ National University of Malaysia (UKM), Malaysia \\ E-mail: csiwar@ukm.my \\ Md. Mahmudul Alam \\ PhD Candidate \\ Institute for Environment and Development (LESTARI) \\ National University of Malaysia (UKM), Malaysia \\ E-mail: rony000@gmail.com \\ * Corresponding author
}

\section{Citation Reference:}

Hossain, M.I., Siwar, C., and Alam, M.M. 2013. Challenges of Community based Fish Culture Program in Bangladesh: Case Study on Floodplain Beel Mail in Rajshahi. Journal of the Institute of Bangladesh Studies, Vol. 36, pp. 129-136.

This is a pre-publication copy.

The published article is copyrighted by the publisher of the journal. 


\title{
CHALLENGE OF COMMUNITY BASED FISH CULTURE PROGRAM IN BANGLADESH: CASE STUDY ON FLOODPLAIN BEEL MAIL IN RAJSHAHI
}

\author{
${ }^{1,2}$ MI Hossain*, ${ }^{2} \mathrm{C}$ Siwar, ${ }^{3} \mathrm{MM}$ Alam \\ ${ }^{1}$ Department of Fisheries, University of Rajshahi, Bangladesh, bitanrubd@yahoo.com \\ ${ }^{2}$ Institute for Environment and Development (LESTARI), Univesiti Kebangsaan Malaysia \\ (UKM), Malaysia \\ ${ }^{3}$ School of Economics, Finance \& Banking (SEFB), College of Business (COB), \\ Universiti Utara Malaysia (UUM)
}

\begin{abstract}
Bangladesh is one of the largest and richest floodplain lands in the world. There are 3 million hectares of medium and deep flooded areas. In the dry season these land are used for rice production, but these lands remain unutilized or underutilized for a long period because of flooding. Recently, rice and fish culture is practiced in dry and flooding season under community based fisheries management (CBFM) in Kalmina Beel, Fulbaria, Mymensingh and Angrar Beel, Pirganj, Rangpur areas as case studies. Assessment of the challenges and problems of these beels will help to implement it in other floodplain areas of Bangladesh that will help utilize land and waterbodies with a good source of food, employment and better income source for poor people. To understand the challenges of implementation of CBFM, this study was conducted on Beel Mail at Rajshahi in Bangladesh as a case study. This study conducted focus group discussion among the CBFM stakeholders. It was revealed that lack of skills, education, technological knowledge, and conflict among the stakeholders are the main internal constraints. Lack of coordination among the government agencies, improper facilities for marketing, infrastructure, and financial services, and environmental externalities were identified as major external constraints of successful implementation of CBFM. Some policy recommendations for the successful implementation of the CBFM have been formulated.
\end{abstract}

Keywords: Floodplain, Beel, Fish-Rice culture, Community based fish culture

\section{Introduction}

Floodplains are important aquatic ecosystem that support wide range of biodiversity and provide indispensable benefits to the people. Bangladesh is said to be the world's largest floodplain with $80 \%$ floodplain land area. The country has a great opportunity to improve its economy by aquaculture. As seasonal flood is part of life here, flood water can be blessings if managed properly for producing food. The seasonal water bodies which remain inundated for 4-6 months each year remain unutilized in terms of managed aquatic resources. These floodplains are used only for dry season rice cultivation and wild fish catch in monsoon. These waterbodies are assumed to be 
unsuitable for fish culture as fish leave out with flooding and also because of short term existence of water.

The inland open waterbodies of Bangladesh were rich sources of fishes from ancient time. Therefore culture of fish was never the management issue for the concerned authority for long years. After liberation, the Ministry of Land (MOL) managed these inland open water fisheries with the view of raising revenue by leasing these fisheries to the highest bidder for short term period (one year for jalmahal and three years for beel). But during flooding these jalmahal areas could not be defined and would become the public property. Even during post monsoon period, poor subsistence fisher had open access to the jalmahal for collecting small indigenous fishes. This would benefit the landless poor fishers (Hossain et al. 2010; Ali 1997; Bernacsek 1994) but hindered the appropriate management of these fisheries (Hardin 1968) because of lack of control over the beel and lack of initiatives by the lease holders. This resulted in over exploitation of these water bodies (Aguero 1989; Bernacsek 1994; Hossain et al. 1998). In 1973 government restricted the leasing to registered fisher co-operatives, the revenue oriented strategy continued to result in over fishing and exploitation of the poor fishers by the lease holders and their intermediaries.

In floodplain beels of Bangladesh fish production has dropped down to 50-55\% and this is due to environment degradation which includes human interventions through construction of flood control embankments, drainage system and sluice gates, conversion of inundated land to crop land-thereby reducing water area and indiscriminate use of pesticides and insecticides, pollution from domestic, industrial and agro-chemical wastes and run-off have resulted in extinct of a considerable amount of an aquatic biota in some stretches of the open water system (Mazid \& Hossain 1995). Hoque (1995) also described that fish diversity is decreasing. There are now 13 critically endangered, 28 endangered and 14 vulnerable fish species out of a total of 296 freshwater/brackish fish species existing in Bangladesh.

Sadeque (1992) pointed out to resource use, conflict, improper infrastructure, and lack of restocking, indiscriminate pesticide use and over fishing as the cause of this decline. Ali et al. (1995) noted that apart from the disruption of the natural cycle of fish migration, reproduction and growth, agricultural expansion and agro-industrial pollution have contributed to this decline estimated to be between 3 and 10 percent per year. Alam and Thomson (2001) demonstrated that a host of factors are responsible for the underutilization of fishing areas, including resources limitation, poor implementation of fisheries laws, the limited spread of fish farming technology, low financial capacities and 
ineffective production practices. Shankar et al. (2005) stated that, abstraction of surface water for irrigation poses a serious threat to the sustainability of floodplain fisheries in Bangladesh. This externality imposed on the fishery has important consequences for millions of poor who depend on fishing for their livelihoods, and several trends indicate the problem is likely to worsen in the future.

The continuing decrease in fish catch increasingly threatens the livelihoods of more than 12 million fishers in Bangladesh (Hossain et al. 2010; Hossain et al. 2006). Government policies were not appropriate to initiate fish culture in these seasonal waterbodies. Even economic condition of floodplain fishes, inadequate knowledge for managing these waterbodies and influence of elite money lenders hindered the appropriate management of these waterbodies. Despite taking some management actions by the government to remove exploitation of the original fishers from influential elites, all the actions failed and it was understood that floodplain management should include these intermediaries rather to avoid them.

In the community based approach, participation of different stakeholder groups of a defined area is to be ensured in decision making and in thorough management for the sustainable development of local resources. So, community based fisheries management (CBFM) refers to management approach for maintenance and sustainable enhancement of fisheries resource with greater community participation which aims at strengthening community responsibility for resource management and reducing government control over them. CBFM has become a common strategy for improving management of natural or common pool resources and empowering local communities through co-management, using local knowledge, recognizing local institutions and establishing common property regimen (Hossain et al. 2010; Berkes et al. 1998; Ostrom 1990; Pomeroy \& Berkes 1997). Therefore in 1996, the community based fisheries management (CBFM) started functioning in some water bodies with the involvement of government (Hossain et al. 1999), non-government organizations and local community members with the aims of equitable distribution of benefits to all the stakeholders and to developing fishery management system that is more equitable and ecologically sustainable. World Fish and International Fund for Agricultural Development (2002) report, have shown that with CBFM approach in shallow and deep flooded rice fields' fish production can be increased to as much as $600 \mathrm{~kg} \mathrm{ha}^{-1} \mathrm{yr}^{-1}$ and 1.5 ton $\mathrm{ha}^{-1} \mathrm{yr}^{-1}$, respectively. Community-based cooperative fisheries approach has led to increased fishing effort, encouraged excessive fishing investment and thus, declining catch trends. 
After introducing CBFM, there were very few studies conducted on the problems that faced by this approach. It can be also expected that, if successful, CBFM will create opportunity for Bangladesh economy to get more returns from this unutilized waterbodies and this field will provide a good source of food, employment and income source to poor fishermen. Assessment of the current problems of these wetlands CBFM needs to be known considering the existing and potential water resources so that management actions can also be taken to improve. To understand the implementation effect of CBFM, this study identifies the constraints prevailing there.

\section{Methodology}

\section{Study Area}

Beel Mail was selected for this study is under Mohanpur Sadar district of Rajshahi in Bangladesh. Mohanpuris situated between $24^{\circ} 28^{\prime}$ and $24^{\circ} 38^{\prime}$ north latitude and between $88^{\circ} 34^{\prime}$ and $88^{\circ} 43^{\prime}$ east latitude having an area of $162.65 \mathrm{sq} \mathrm{km}$. The location of the study areas showed in the map (Figure 1).

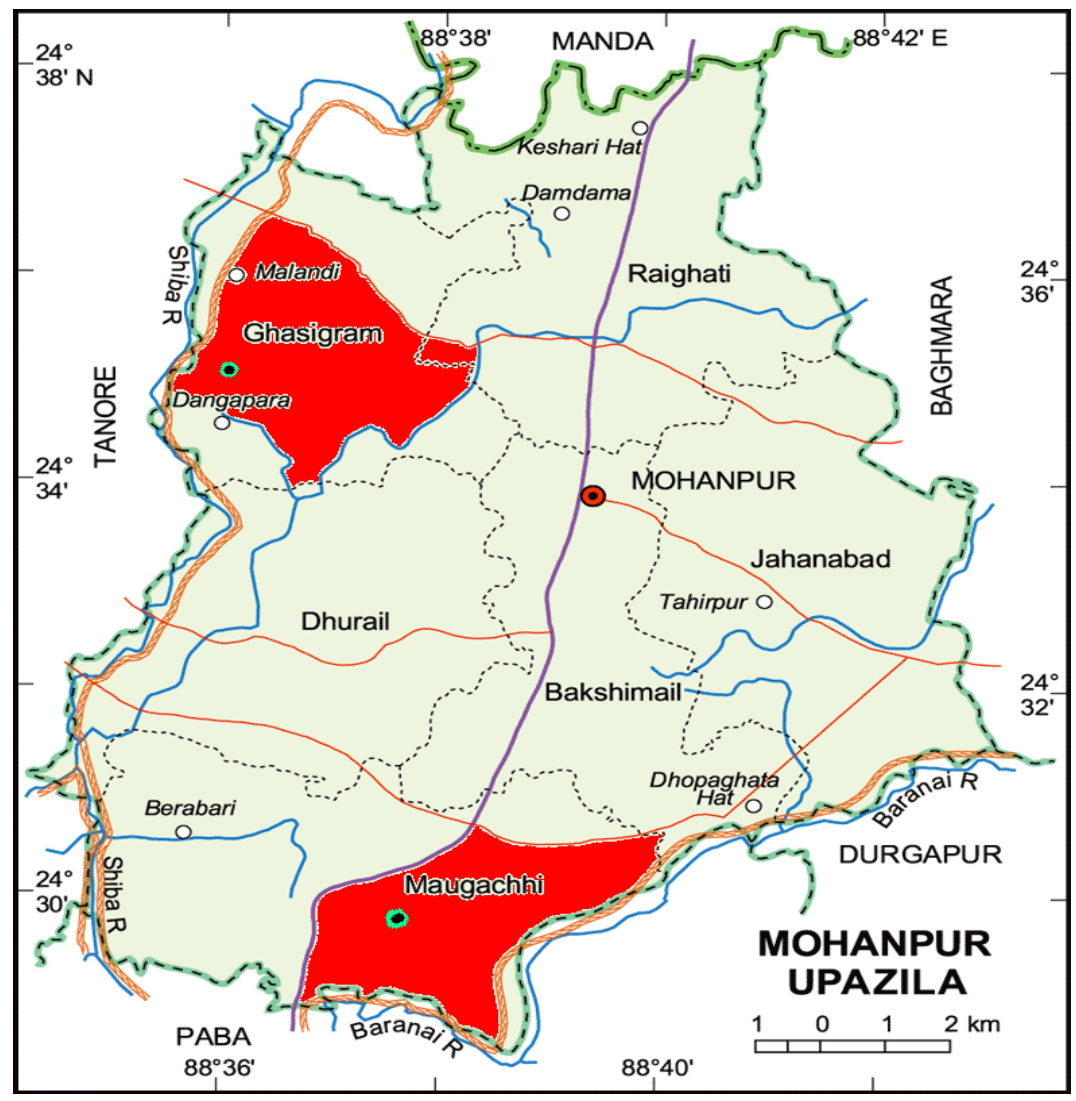


Figure 1: Map showing selected study areas in Mohanpurupazila

Source: http://banglapedia.search.com.bd/HT/N_0049.htm

It is open beel that is shallow depressions where land is converted to agriculture while permanent water is limited to deeper areas during dry season connected nearby a local Shiba River, which further connected to Padma river basin. This floodplain beel is mainly privately owned lands with total 100 ha area of which 15 ha government Khas lands having water availability for 5-6 month. For long time this beel is being used for fishing by group of poor fishers (both from caste Hindus, few of them from Muslim community). They have access and control in the entire floodplain during monsoon without conflict with the private landowners. There are rivers and perennial floodplain in the nearby area. Melandi, Goalpara, Dangapara and Moheskundi villagers are the main beneficiaries of this beel. The community based fish culture was intervened by DoF with the funding support of Challenge program for water and food project, South-east Asia, World Fish.

\section{Data Collection}

Data were collected through focus group discussion (FGD) to identify major constraints of implementing CBFM. Constraints and opportunities for CBFM sorted out here are the combination of problems mentioned by the community members and the problems experienced by researcher during community formation and introducing fish culture in the respective floodplain beels.

Two FGD sessions were conducted in beel area with participation of village leaders, landowners, landless fishermen, and other beneficiaries of beel, Department of Fisheries (DOF) and World Fish staffs. Meeting was officially arranged by World Fish stuffs in office of Upazila fisheries officer with community leaders and executive group members.

\section{Findings and Discussions}

From the FGD, it was found that the people faced several constraints for successful implementation of the CBFM in that beel. These challenges come from their own management as well as socioeconomic, cultural and policy issues.

Among the constant faces the fisherman, lack of skills and technological capacity are the major issues that come from their own. These fishermen are not educated enough, and they do not have scientific and technical knowledge regarding floodplain aquaculture and modern fishing technique. At the same time they also do not have enough equipment and training facilities as well as supervision. Department 
of Fisheries (DOF) organized a training program with the support of experience resource persons on community based fish in open water floodplain beels. Training was provided on water quality of floodplain beels for fish culture, fish stoking, quality and quantity of fish fingerlings, water body management, modern fish harvest, fish marketing and group saving scheme. But this training is not adequate for them.

Here fishermen follow the traditional method of fish culture. If this traditional fish culture is possible to improve with supplementary feeding and fertilizer, stocking density can be raised and hence more production from unit water area during short time is possible. Stocking of fish fingerlings is one of the most important factors to manipulate for increasing fish production. Stocking strategy affirms to stocking density, species composition, fingerlings weight and time of stocking. Stocking density of 5000 fingerlings/ha for carp fish culture for optimizing yield (Hasan et al. 1999), but stocking density of fish fingerlings in project beel was only 747 fingerlings/ha water body that is far below the recommended stocking density. Stocking weight of fingerlings is also responsible for enhanced production as recovery of fingerlings decreases at lower stocking weight due to either predation or transportation mortality or both (Hasan et al. 1999). They recommended for stocking weight of carp fingerling in oxbow lake to be $35-45 \mathrm{~g}(12-15 \mathrm{~cm})$. In the beel Mail though most of the carp fingerlings were of recommended weight or more than that, Mrigal (Cirrhinus mrigala) was of low weight.

Stocking density and fish growth depends on food availability in water body. Thus supplementary fish feeding can ensure optimum growth of fish during short period, but in the beel Mail no fish feeding was applied. Fertilizers are also important for fish production. Urea, TSP is chemical fertilizers which enhance growth of phytoplankton and zooplankton on surface of water body. Thus surface feeder fish get enough food for growth. Manure is organic fertilizer that enhances benthos (snails) production. This is the food mainly for bottom feeder fish. In project beel no fertilizer was applied during fish culture.

Disease can create a serious threat to aquaculture. As these waterbodies are short lasting, water is naturally fresh and less polluted. But when intensive or semi intensive fish culture will be practiced, disease can occur. Usually disease occurs due to excess stocking of fish fingerlings, decomposition of unutilized fish feed and application of more fertilizer resulting in reduction of dissolved oxygen in water, but in this study traditional fish culture was practiced. However this beel area is mainly used for rice cultivation so that in the dry season usage of chemical fertilizer and 
insecticides during rice cultivation harms fish growth and increase the risk of fish mortality.

Environmental externalities and disasters also considered as strong barriers for the economic return of fish productions. Water level of the seasonal floodplain varies with time and influences the water quality, aquaculture and the management approaches. This variation in water level happens due to fluctuation of rainfall and water level change of connecting river. Excess rainfall and raise of water level in the connecting river can cause over flooding and can create a problem to aquaculture and financial loss. Seasonal floodplain beels when have poor embankments and are connected to river become difficult to manage and to fence. Again fencing in these beel is costly and farmers cannot fence the area properly due to funding constraint. And during over flooding, water level can raise beyond fencing height which leads to escape of cultured as well as SIS fish species and cases lesser the production.

Funding is one of the major constraints for fish culture. Money is required for leasing the water body, for buying fish fingerlings, for fencing, netting, and providing supplementary feeding, for fertilizer and all other harvesting and post harvesting activities. But economic conditions of fish farmers are not well enough to support the costs of fish culture. Though World Fish funded for fingerlings, fencing, net, boat and also arranged for revolving fund for lease money and for fingerlings, still enough money is required to optimize fish production by improved traditional fish culture i.e. by providing supplementary feeding, fertilizer and by increasing stocking density. When fishermen don't have sufficient money for fish culture, they have to search for money from Bank, NGOs or local money lenders. In Bangladesh, the credit situation of public sector is very complicated.

Infrastructural problem is another major constraint for the success of the CBFM. Most of the local markets don't have enough facilities for electricity, water, ice, etc. It is believed that 30 to $33 \%$ of all fish caught become unsuitable for human consumption due to infrastructural problem (FAO 2001). Due to lack of preservation facility and poor transportation, fishers had to sell their product in local market, but the purchasing ability of the villagers is also poor. There is no standard of pricing thus middle men buy from the local market in very low price.

Poor marketing facility is another major constraint faced by the fishermen in the floodplain beels. At the primary level market is mainly controlled by a group of middle men known as Arothdars and Mahajons. Broadly used fish market channel is 'Fishermen $\rightarrow$ Bapari $\rightarrow$ Aratdar $\rightarrow$ Paiker/ whole saler $\rightarrow$ Retailer $\rightarrow$ consumer'. Small number of whole saler and lack of good communication facilities cause noncompetitive and monopoly types of market. 
Government policy and institutional coordination problems are also strong barriers for the sustainable growth of the success of CBFM. Long-time leasing is a pre-requisite for success of CBFM and also for sustainable development of seasonal waterbody. If long term leasing right can be ensured, community members feel committed for developing these water body for improving their livelihoods. Current leasing system allow only for three years. The floodplain lands become the government property during flooding and are dealt by the MOL, but waterbody should be managed by DOF. At the same time Ministry of Fisheries (MOF) also needs to coordinate the issues. If CBFM also register, it needs to go to the Ministry of Lands.

There are few challenges within the CBFM per se. There are conflicts among the stakeholders is very common. Generally water levels vary with the seasons that directly affect the total area of shallow fringe lands around the beel where paddy can be grown during the dry season. When there is little flood, rapid drainage of the beels by paddy cultivators, immediately after the rainy season, causes conflict with fishermen. The fringe lands are part of the beel for which fishers groups pay the lease fee, but these plots are in fact "informally owned" mostly by non-fishers farmers, who have no interest in maintaining high water levels for fish. Also usages of pesticides in the rice fields during dry season causes to accumulate it in the deeper portion of the beel through washing away by rain water during rainy season that reduces fish growth and also causes fish mortality.

Another very important internal constraint of CBFM is the conflict between the land owners and the landless fishermen. The land owners did not agreed to include original fishermen and the landless people of that community. General problems regarding community formation were in developing a concept of common property rights, social and political conflicts in following sharing systems, disobedience of the property rights by land owners, lack of trust and sacrificing mentality among the group members, non-cooperation by the village people outside the community. After several meetings, community was formed including both landowners and landless fishermen and this community successfully carried on fish culture during first year and profit was shared among these two groups according to pre-agreed sharing arrangements.

\section{Conclusion and Policy Recommendations}

This study reveals that community based fish culture in the seasonal floodplain beel is socially acceptable and economically profitable, and this approach benefits the landless poor fishermen by involving wide range of original fishermen in fish culture activities. It helps in better sharing of benefits among the landowners and landless 
fishermen. It is expected that community based fishery management approach also able to restrict exploitation of the poor original fishers by money lenders and other elite influential in these open waterbodies by strengthening the bonding within fishermen society and by making them economically strong. For successful CBFM it is also essential to identify, explain and removal of constraints of fish culture in seasonal open waterbodies. Low stocking density, dependence on natural fish feeding, less technical skill of fishermen, less control over market, funding constrain, environmental externalities, leasing system of water body and conflict between stakeholders, lack of coordination among respective government ministries were identified as major constrains of successful implementation of CBFM, and for achieving optimum return from fish culture in the floodplain beel areas.

Several policy options are needed to overcome the constraints for better management in CBFM in Bangladesh. In the beel Mail, stocking density should be raised to enhance total fish production as well as fingerlings weight should be maintained to increase fish production during short period of flooding. To conserve the brood of small indigenous fish species (SIS) sanctuary can be established, and nursery pond development also needed to be added to promote timely stocking of these water body with good quality fingerlings. At the same time, fertilizers should be applied to ensure food availability at all level of water body for optimum growth of fish. Rice husk, duck weed can be used in the water body as supplementary fish feeding and organic fertilizers. To solve financial constraint for fish production, government should arrange easy and soft fund for the CBFM community. Microcredit also can provide at lower interest rate for inland open water fisheries sector. Government also should take initiative to perform infrastructural development and monitoring the market. The period of leasing contract needs to increase for a successful growth. Finally, for successful implementation of CBFM in this common property, both landowners and landless people should be involved. If landowners get benefits of fish culture, they will promote fish culture in rainy season instead of going for confrontation with fishermen. Thus the rice cultivators will be acknowledged and motivated to practice natural pest control technique in rice fields to avoid detrimental effect of pesticide on fish culture. To establish right of original fishermen on this common water body gradual empowerment is required which can be achieved by strengthening the social bonding among the group members. If the mentioned constraints can be possible to properly introduce, the CBFM in beel mail will become a very successful story.

\section{Acknowledgements}

The authors would like to acknowledge the financial support for this research from the World Fish (Community Based Fish Culture in Irrigation System and Seasonal 
Floodplain Project (CP35) funded by CGIAR Chellenge Program Water \& Food, April 2005 -31 Dec 2010) and Malaysian Commonwealth Scholarship (MCS), Ministry of Higher Education, Malaysia (Ref. KPT (BS) 035/11/002, 15.2.200631.5.2009).

\section{References}

Aguero M. Inland water fisheries of Bangladesh: management options and national interventions. In: Aguero, M., Huq, S., Rahman, A.K.A., Ahmed, M. (Eds.). Inland Fisheries Management in Bangladesh. Department of Fisheries, Dhaka, Bangladesh; Bangladesh Centre for Advanced Studies, Dhaka, Bangladesh, and International Centre for Living Aquatic Resources Management, Manila, Philippines (1989): 149.

Alam M. F. \& Thomson K. J. Current constraints and future possibilities for Bangladesh fisheries. Food Policy.26(3) (2001): 297-313.

Ali M.Y. Fish, Water and People: Reflections on Inland Openwater Fisheries Resources of Bangladesh. University Press, Dhaka (1997).

Ali M.L. \& Fisher K. Potential, constraints and strategy for conservation and management of inland open water fisheries in Bangladesh. Paper presented at the National Workshop on Fisheries Resource Development and Management. MOFL, ODA and FAO, Dhaka, Bangladesh (1995).

Berkes F. Property rights and costal fisheries, 51-62. In R.S. Pomeroy (ed.) proceeding of the conference on Community management and common property of costal fisheries in Asia and the Pacific: concepts, methods and experience. ICLARM 45 (1994): 196.

Berkes F., Feeny D., McCay B.J. \& Acheson J.M. The benefits of the commons. Nature 340 (1998): 91-93.

Bernacsek G.M. Socio-economic constraints impeding implementation of the New Fisheries Management Policy in Bangladesh. In: Proceedings of the IPFC Symposium held in Conjunction with the 24th Session of IPFC on Socioeconomic Issues in Coastal Fisheries Management. FAO (1994): 248-258.

FAO. The economics of conservation agriculture. Rome, Italy: FAO, Land and water development division, Food and Agriculture organization of the United Nations (2001).

Hardin G. The tragedy of the commons. Science.162 (1968): 1243-1248. 
Hasan M.R., Bala N. \& Middendorp H.A.J. Secchi disc as a tool to determine stocking density and predict fish yield in a culture-based fishery. 159-168 In: H.A.J. Middendorp, P.M. Thompson, R.S. Pomeroy (Eds.) Proceedings of the Conference on Sustainable Inland Fisheries Management in Bangladesh. ICLARM, Vol. 58, Manila, Philippines (1999).

Hoque M. T. 'Sustainable agriculture - a perspective on fish culture for the small scale resource-poor farmers of Bangladesh'. Journal of Sustainable Agriculture 5(3) (1995): 97-113.

Hossain MI., Siwar C., Mokhtar MB., Dey MM. \& Jaafar AH. Impact of Community Based Fish Culture on Seasonal Floodplain Beel - A Comparative Study. J. Sci. Res. 2 (2) (2010): 369-379.

Hossain M.M., Rahman S.A. \& Thompson P.M., Building government-nongovernment organization-fisher partnerships for fisheries management in Bangladesh. In: Proceedings of the Seventh Annual Conference on the International Association for the Study of Common Property, Vancouver, Canada. http://www.indiana.edu/iascp/Drafts/hossain.pdf., $\left(4^{\text {th }}\right.$ May 2007) (1998).

Hossain M. M., Kabir M. S., Thompson P. M., Islam M. N. \& Kadir M. M. Overview of the community based Fisheries management Project, p.9-18. In H.A.J.Middendrop, P.M.Thompson and R.S. Pomeroy (Eds.) Proceeding of the Conference on Sustainable inland fisheries management in Bangladesh, ICLARM (1999): 58, 280.

Mazid M.A. \& Hossain M. S. Development of fish resources in floodplains. FRI Publication No. 12, Fisheries Research Institute, Mymensingh, Bangladesh (1995): 29-31.

Monir Hossain M., Islam M.A., Ridgway S., \& Matsuishi T. Management of inland open water fisheries resources of Bangladesh: Issues and options. Fisheries Research. 180 (1-3) (2006): 275-284.

Ostrom E. Governing the Commons: The Evolution of Institutions for Collective Action. Cambridge University Press, Cambridge, MA (1990).

Pomeroy R.S. \& Berkes F. Two to tango: the role of government in fisheries comanagement. Marine Policy. 21 (5) (1997): 465-480.

Sadeque S.Z. Capture fisheries and other common property resources in the floodplains of Bangladesh. J. Sci. Stu.Dhaka. 55 (1992): 20-34. 
Shankar B., Halls A. \& Barr J. The Effects of Surface Water Abstraction for Rice Irrigation on Floodplain Fish Production in Bangladesh', Int. J. Water. 3 (1) (2005): 61-83.

Worldfish Center Increasing and Sustaining the Productivity of Fish and Rice in the Flood-Prone Ecosystems in South and Southeast Asia. Final Report to the International Fund for Agricultural Development, Worldfish Center, Pinag, Malaysia (2002): 95. 